\title{
A mágneses magrezonancia spektroszkópia (NMR) alkalmazása a kolloidok fizikai kémiai jellemzésére
}

\author{
KÉRI Mónika, NAGY Zoltán, NOVÁK Levente, NYUL Dávid és BÁNYAI István* \\ Debreceni Egyetem, Fizikai Kémiai Tanszék, Egyetem tér 1. Debrecen, Magyarország
}

\section{Bevezetés}

A kolloidok fizikai kémiája nem csak önmagában érdekes, hanem a fizikai kémia általános fejlődéséhez is nagymértékben hozzájárult ${ }^{1}$. A nagymüszeres szerkezetvizsgáló módszerek, mint például a mágneses magrezonancia (NMR), a nanotechnológia viharos gyorsaságú megjelenésével a kolloidok fizikai-kémiájában is gyorsan teret hódítottak ${ }^{2}$. A nagyfelbontású NMR alkalmazásával elsősorban a különböző fehérjék szerkezetvizsgálatában értek el alapvető eredményeket. E területen hazánkban több mühely is a nemzetközi élvonalhoz tartozik. $^{3-6}$ A klasszikus diszperziós kolloidok és nanorészecskék vizsgálatában az NMR alkalmazások még csak az utóbbi évtizedekben kezdődtek. ${ }^{7-9}$ A Debreceni Egyetem Fizikai Kémiai Tanszékén, illetve az előd Kolloidés Környezetkémiai Tanszéken mintegy tíz éve indultak meg az ilyen irányú kutatások. ${ }^{10}$ Ezek sem elsősorban a nagyfelbontású korrelációs $1 \mathrm{H}, 13 \mathrm{C}$ egy- és kétdimenziós NMR vizsgálatok voltak, bár ezek sem hiányoznak az eszköztárunkból ${ }^{11,12}$, hanem a kevésbé alkalmazott dinamikus NMR mérések, úgymint diffúziometria és relaxometria, valamint a reneszánszát élő NMR-krioporozimetria.

E dolgozatban az utóbbi tíz év néhány eredményét mutatjuk be, elsősorban az NMR alkalmazása szempontjából. Ennek oka az, hogy a módszer még kevéssé terjedt el az egyébként világszínvonalú magyar kolloidikában, nanotechnológiában és a kapcsolódó anyagtudományi kutatásokban. Célunk az, hogy az ezen a területen dolgozó tudományos közösség számára megmutassuk a módszer teljesítőképességét, illetve a hazai NMR spektroszkópusok számára ízelítőt adjunk, hogy milyen lehetőségek vannak számukra a nanotudományokban. ${ }^{2,13}$

Bemutatandó modellrendszerként döntően a poli-amido- amin dendrimereket választottuk, leggyakrabban azok ötödik generációját. (G5_PAMAM.NH $\mathrm{N}_{2}$ ). Ezek szimmetrikus, közel gömb alakú, monodiszperz makromolekulák, a G5_PAMAM.NH$H_{2}$ ötödik generációs alapmolekula moláris tömege $28 \mathrm{kDa}$. Az 1. ábrán ennek egyszerüsített szerkezeti képlete, és kiterített vázlata látható. Fontos tulajdonsága, hogy a reaktív $\mathrm{NH}_{2}$ végcsoportok könnyen funkcionalizálhatók, például karboxil csoportokkal, ami nanoméretü kelátképzők előállítását teszi lehetővé. Amennyiben a nem funkcionalizált amino végcsoportokat szubsztituálják, például metilezik, akkor a dendrimerek toxikus hatása megszüntethető. ${ }^{14}$ Hátrányuk a viszonylagos drágaságuk és - elsősorban a nagyobb generációknál - a reprodukálható előállításuk nehézsége. ${ }^{15}$

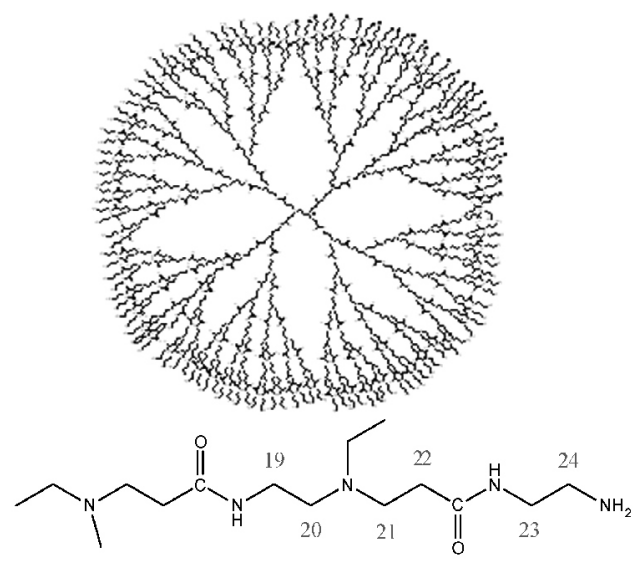

1. ábra Egy PAMAM dendrimer síkban kiterített vázlatos szerkezeti képlete (felső ábra). A G5 PAMAM. $\mathrm{NH}_{2}$ dendrimer végcsoportja az etilén-diamin maghoz kapcsolódó ötször ismétlődő egységekkel (alsó ábra).

\section{Kísérleti rész: az NMR módszerek rövid ismertetése}

\subsection{Az NMR diffúziometria}

Az NMR diffúziometria (PGSE-NMR vagy kétdimenziós változata, a DOSY) a molekulák vagy részecskék hőmozgásának sebességét méri. ${ }^{16}$ A z-irányú mágneses gradiens impulzusok kiadására képes NMR-készülékek és mérőfejek megjelenésével, valamint a vonatkozó méröprogramok kifejlesztésével ez a módszer a diffúziós együtthatók meghatározásának egyik alapvető módszerévé vált ${ }^{17}$. Ahhoz, hogy egy molekula vagy részecske diffúzióját tanulmányozhassuk, a részecskének egy jól mérhető NMR-aktív magot kell tartalmaznia. A diffúziósebesség méréshez fontos a viszonylag nagy érzékenység és a hosszú relaxációs idő.

A módszer elve röviden a következő. Az NMR-cső hossztengelye mentén ( $z$-irány) rövid ideig (néhány $\mathrm{ms}$ ) létrehozunk egy viszonylag nagy mágneses tér gradienst (a szokásos maximum érték 50 Gauss $/ \mathrm{cm}$ ). Ennek a következménye az, hogy az azonos részecskék kémiai eltolódása (mágneses momentumának precessziós frekvenciája) attól fog függeni, hogy éppen hol tartózkodnak az NMR cső hossztengelye mentén. A gerjesztő impulzussorozat megszünése után a relaxáció sebessége pedig két tényezőből adódik össze: a valódi relaxációból és a cserefolyamatokból származó sebességtöbbletből. Itt a

\footnotetext{
* Bányai István. Tel.: +36 52 512900/22384, e-mail: banyai.istvan@science.unideb.hu
} 
cserefolyamat pedig nem más, mint a részecskék Brown-mozgásából származó z-tengely menti helycsere. Az így kialakult megnövekedett relaxációsebességet a mért jel intenzitásának csökkenéséből számolhatjuk ki a következö egyenlet segítségével:

$$
I=I_{0} \exp \left(-\frac{\tau_{1}}{T_{2}}-\frac{\tau_{2}}{T_{1}}\right) \exp \left[-\gamma^{2} g^{2} D \delta^{2}\left(\Delta-\frac{\delta}{3}\right)\right]
$$

Ahol $\tau_{1}$ az idő, amely alatt csak transzverzális relaxáció történik, $\tau_{2}$ amely során longitudinális relaxáció és a cserefolyamat (Brown-mozgás) következik be míg $\delta$ a $z$-irányú gradiens impulzus időtartama. $\Delta=2 \times \tau_{1}+\tau_{2}$, azaz az ún. diffúzió idő, amely alatt a cserefolyamat, azaz a Brown-mozgás történik és befolyásolja a jelintenzitást. A mérés során a $g$ gradiens térerősséget fokozatosan növelve mérjük a jelintenzitást, majd a $\gamma$ giromágneses együttható értékét ismerve a $D$ diffúziós együttható a legkisebb négyzetek módszerével kiszámítható ${ }^{16}$. Az angol nyelvi szakirodalom gyakran „self-diffusion"-nak nevezi a folyamatot, a magyar szaknyelvben a saját diffúzió használatos. A mi javaslatunk a Brown-mozgás megtartása, vagy reverzíbilis diffúzió kifejezés használata, mivel a rendszerben kémiai potenciálkülönbség nincsen.

\subsection{NMR relaxometria}

Az NMR relaxometria a relaxációs idő mérésén alapul. Az NMR relaxációs mechanizmusok sokfélék, de ezek közül a legtöbb esetben, nem kvadrupólus magok esetén, az ún. dipoláris relaxáció határozza meg a gerjesztett állapot megszűnésének sebességét. Ebben szerepet játszanak a környezet mágneses és dielektromos tulajdonságai, a környezeti mágneses fluktuáció frekvenciája és annak viszonya a gerjesztett magot tartalmazó molekula nem transzlációs mozgásának frekvenciájához. Ez utóbbit a rotációs korrelációs idővel jellemezzük, ami egy radiánnyi fordulat ideje. Ez kapcsolatos a molekula mozgási szabadsági fokaival, illetve méretével. Minél lassabb a molekula mozgása annál gyorsabb mind a transzverzális, mind a longitudinális relaxáció. Ezt a tényt mi elsősorban a porózus szilárd testek vizsgálatára használjuk ki. Az alkalmazás igen jól müködik kisfelbontású NMR készülékeken is ${ }^{18}$. Ezek a viszonylag olcsó relaxométerek igen hatékonyan alkalmazhatóak például pórusméret meghatározására. E munkánkban jelentős szakmai és szoftvertámogatást kaptunk Ioan Ardelean professzortól a kolozsvári Műszaki Egyetemről, aki a kisterü NMR nemzetközileg elismert szakértője, és az alkalmazásáról számos közleményt publikált ${ }^{19-21}$. A relaxáció sebességét hagyományosan a $T_{1}$ és $T_{2}$ longitudinális és transzverzális relaxációs időállandókkal jellemzik, amelyek a relaxáció elsőrendü sebességi koefficienseinek reciprok értékei.

\subsection{NMR krioporozimetria}

A kriporozimeztria elve régóta ismert a fizikai kémiában. Az ún. Gibbs-Thomson egyenlet írja le azt, hogy zárt térben folyadékok fázisátmeneti hőmérséklete hogyan függ a tér méretétől. Például olvadás esetében:

$$
\Delta T=\left(T_{e}-T_{0}\right)=-\frac{V_{M} \gamma_{s l} T_{0}}{\Delta H} \frac{A_{S}}{V_{S}}=-K_{\mathcal{C}} \frac{A_{S}}{V_{S}}
$$

A (2) egyenletben bal oldalon az olvadáspont-csökkenés szerepel. A jobb oldalon a folyadék moláris térfogata $\left(V_{\mathrm{M}}\right)$, a folyadék-szilárd határfelületi feszültség $\left(\gamma_{s l}\right)$, az olvadáspont nagy térben $\left(T_{0}\right)$, az olvadáshő $(\Delta H)$ és a felület-térfogat arány szerepel $\left(A_{\mathrm{s}} / V_{\mathrm{s}}\right)$. Látható, hogy ez utóbbi mikor kicsi, azaz a zárt tér nagy, akkor az olvadáspont-csökkenés zérushoz tart. Az említett fizikai-kémiai paramétereket a $K_{\mathrm{c}}$ kriporozimetriás állandóban gyüjtötték össze, majd kísérleti adatok alapján módosították adott rendszerekre.

Az NMR spektroszkópia ennek a régi módszernek a reneszánszát hozta, ugyanis a szilárd (megfagyott) fázis megfelelö mérési módszerrel (spin-ekhó) nem ad jelet ${ }^{22,23}$. Ha tehát egy porózus anyagot tartalmazó, oldószerrel telített mintát megfagyasztunk, akkor az oldószer NMR-jele a gyors relaxációja miatt nem látható. Ha részben megolvad, akkor viszont kvantitatívan mérhető az olvadt rész mennyisége. Ez azt jelenti, hogy lépésenként emelve a fagyott minta hőmérsékletét észlelni tudjuk először a kisebb pórusokban megjelenő olvadt folyadék mennyiségét, a hőmérsékletből pedig az $A_{\mathrm{S}} / V_{\mathrm{s}}$ arányt számíthatjuk ki, ami például gömb esetében $3 / r$ azaz a pórus sugarával van összefüggésben ((2) egyenlet). A módszer érdekessége, értéke még az, hogy a fagyás- és az olvadásgörbéken bizonyos esetekben hiszterézis észlelhető, amiből a pórus geometriájára tudunk következtetni. A számítások szerint a $\Delta \mathrm{T}_{\mathrm{f}}$ fagyáspontcsökkenés viszonya $\Delta T_{\mathrm{m}}$ olvadáspont-csökkenéshez a geometriára utal. Ha az arányuk 3/2, akkor a pórus gömb ha 2 , akkor hengeres, ha nincs olvadáspont-csökkenés de van fagyáspontcsökkenés, akkor rés alakú a pórus ${ }^{22}$.

\section{Példák az NMR alkalmazásokra a kolloidok vizsgálatában}

\subsection{Nagyfelbontású NMR}

Mivel a PAMAM dendrimerek elég drágák, gyakran felmerül az igény, hogy hasonló tulajdonságú olcsóbb polimerekkel helyettesítsük őket. A nagyfelbontású 1D és 2D NMR spektroszkópiát elsősorban a szerves makromolekulás kolloidok módosítása sikerességének megállapítására alkalmaztuk. Példánkban elágazó polietilén-imin (PEI) funkcionalizálását végeztük monoklór-ecetsavval makromolekulás dendrimerszerü kelátképző nanorészecskék előállításának céljából (CM-PEI). A szintézis hatékonyságát több módszerrel, így pH-potenciometriával és kromatográfiásan is ellenőriztük, de leghatékonyabbnak a kvantitatív ${ }^{13} \mathrm{C}$-NMR bizonyult. Azt használtuk ki, hogy a különböző kötési állapotú szenek kémiai eltolódása nagymértékben különbözik, így a karbonil csoportok jelei jól elkülönülten tünnek fel a spektrumban. A 2. ábrán a kiindulási anyag és a termék ${ }^{13} \mathrm{C}-\mathrm{NMR}$ spektrumát mutatjuk, amiből kiderül, hogy a bevitt $\mathrm{COOH}$ csoportok száma (és a vele együtt bevitt $\mathrm{CH}_{2}$ csoportoké is) egyszerü integrálással nyerhető. Természetesen a módszernek további előnye, hogy a kapott vegyület tisztasága, és amint arra a 3.2. alfejezetben kitérünk, a molekula mérete is gyorsan meghatározható a diffúziós együtthatójának mérése alapján. 
A CM-PEI ígéretes ligandumnak látszik például a lantanoidák vagy mangán(II)-ionok koordinációjára, így MRI kontrasztanyagok fejlesztésére. Eddigi eredményeink arra utalnak, hogy átmeneti fémekkel is nagy stabilitású komplexet képez.

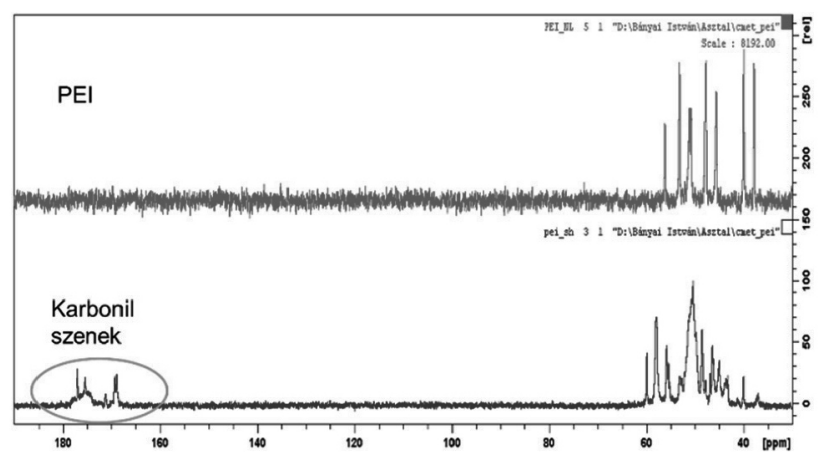

2. ábra. A funkcionalizált (alsó, CM_PEI) és a nem funkcionalizált PEI ${ }^{13} \mathrm{C}$-NMR spektrumai.

A kétdimenziós NMR technikák is hasznosak, az alkalmazásuk hasonló a szerves kémiai rutin alkalmazásokhoz, azonban mindig figyelembe kell venni a makromolekulákra, nagy részecskékre jellemző rövid relaxációs időket. Érdekes példát mutat a 3. ábra, amikor doxorubicin lép kölcsönhatásba ötödik generációs poli-amidoamin dendrimerrel (G5_PAMAM). Egyértelmünek látszott, hogy a gyógyszer sikeres becsomagolását úgy igazolhatjuk, hogy korrelációt mutatunk ki a doxorubicin és a G5 PAMAM NMR jelei között. A kétdimenziós (2D) nukleáris Overhauser-hatás spektrumban (NOESY), amely térbeli közelséget mutatja, nem láthatunk ugyanakkor keresztcsúcsot a doxorubicin és a dendrimer jelei között, csak a doxorubicin saját protonjai között. (3. ábra) A keresztcsúcsok fázisa a doxorubicin saját jelei között azonban megegyezik a diagonális csúcsok fázisával, ami a nagymolekulák sajátsága. Így tudtuk igazolni a hatóanyag kapszulázását, azaz, hogy részévé vált a makromolekulának, de azt nem, hogy mely dendrimer részekhez kapcsolódik másodlagos kötésekkel a hatóanyag kismolekulája ${ }^{24}$.

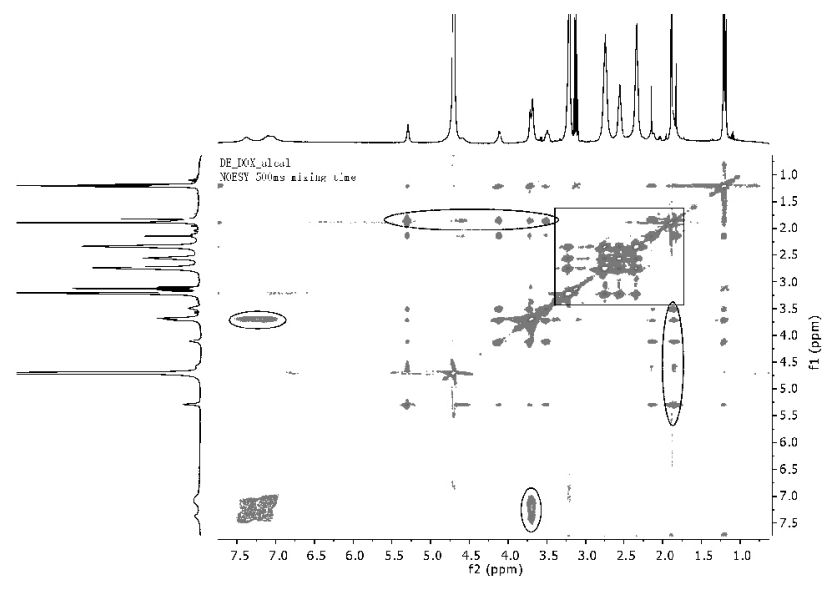

3. ábra. A doxorubicin és G5 PAMAM dendrimer 1H 2D-NOESY spektruma. Négyzettel jelölve a dendrimer korrelációs területe, ellipszissel pedig a doxorubicin aromás jelei közötti keresztcsúcs.
A 3. ábrán érdekességként szaggatott ellipszissel olyan keresztcsúcsokat jelöltünk, amelyek a dendrimer és a doxorubicin protonjai közötti korrelációt mutatnak első látásra. Részletesebb vizsgálataink azt mutatták, hogy ezek kizárólagosan a doxorubicinhez tartoznak, csak a dendrimer jelei átfedték a doxocrubicin jeleit. Ez egyúttal arra inti a felhasználót, hogy a 2D NMR spektrumok elemzését nagy óvatossággal kell végezni.

${ }^{13} \mathrm{C}-\mathrm{NMR}$ technikával sikerült a cellulóz különböző elkülönített frakcióit is azonosítani, amelyeket izotópos kormeghatározáshoz alkalmaznak ${ }^{25}$.

\subsection{NMR diffúziometria alkalmazásai}

Az NMR diffúziometria rendkívüli előnye, hogy gyakorlatilag minden mérhető NMR-magot tartalmazó részecske vagy molekula diffúziós együtthatója meghatározható. Például a nátrium-dodecil-szulfát oldatában, ${ }^{1} \mathrm{H}-\mathrm{NMR}$ segítségével az oldószer és a micella, míg ${ }^{23} \mathrm{Na}-\mathrm{NMR}$ mérésekkel a $\mathrm{Na}^{+}$ellenion diffúzió együtthatója is mérhető. Ezeknek az adatoknak az összevetéséből a rendszer fizikai-kémiai tulajdonságairól érdekes információk nyerhetők. Ebben a rendszerben mérve a dodecil-szulfát anion és a víz diffúziósebességét, meg tudtuk határozni a micella körüli vízréteg vastagságát ${ }^{10}$. A diffúzió NMR-technikával megadott értékek összhangban voltak más adatokkal és más technikák, például a kisszögü neutronszórás eredményeivel ${ }^{26}$.

\subsubsection{PAMAM dendrimerek mérete, asszociációja és hidratációja}

A diffúziós együttható az Einstein-Stokes egyenlet értelmében egyértelmü kapcsolatban van a diffundáló részecskék méretével, amennyiben a részecskék gömb alakúak, és egymás mozgását ütközés vagy egyéb kölcsönhatás révén nem befolyásolják. A poli-amido-amin (PAMAM) dendrimerek az irodalom szerint az első feltételt teljesítik, a második feltételt pedig úgy érhetjük el, hogy meghatározzuk a diffúziós együtthatókat a koncentráció függvényében és zérus koncentrációra extrapoláljuk. Természetesen vizes oldatban a dendrimerek hidratálódnak, aminek természetére pedig a víz $\left(\mathrm{D}_{2} \mathrm{O}\right)$ diffúziósebességének koncentrációfüggéséből következtet-hetünk, mert ${ }^{1} \mathrm{H}-\mathrm{NMR}$-rel mindkét molekula diffúziója követhetö. $\mathrm{A}_{2} \mathrm{O}$ diffúziója a HOD maradék jelen mérhető. A 4. ábra mutatja az $\mathrm{NH}_{2}$ végcsoportú G5 PAMAM. $\mathrm{NH}_{2}$ és a karboxilezett G5 PAMAM.NHCO $(\mathrm{CH})_{2} \mathrm{COOH}$ dendrimerek diffúziós együtthatóinak koncentrációfüggését ${ }^{27}$.

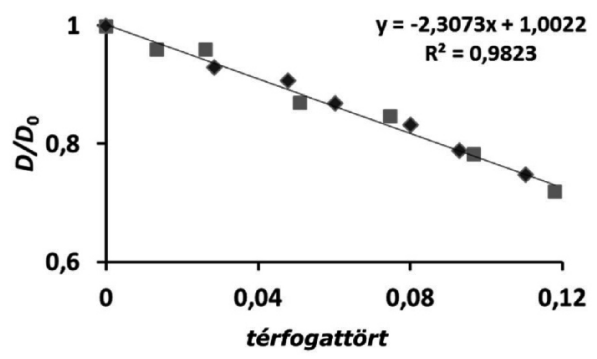

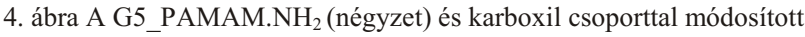
változata (rombusz) relatív diffúziós együtthatóinak függése a dendrimer térfogattörtjétöl. 
A zérus koncentrációra extrapolált diffúziós együtthatóból a G5_PAMAM.NH${ }_{5}$ dendrimer átmérője 6,1 nm-nek adódott, lényegesen nagyobbnak, mint amit más módszerrel becsültek. A térfogattört függvényében ábrázolva a dendrimerek diffuziós együtthatóit a kapott egyenes meredeksége $-2,3$ volt, aminek a merev, gömb alakú kolloidokra elméleti alapon -2,2 kell lennie (4. ábra). ${ }^{28}$ Azaz meglepő módon saját pH-jukon $(\mathrm{pH} \cong 10) \mathrm{a}$ G5_PAMAM. $\mathrm{NH}_{2}$ dendrimer molekulák alap és karboxiláttal funkcionált változatai egymással gyakorlatilag más kölcsönhatást, mint a rugalmas ütközést nem mutatnak, tehát az ideális diszperziós (liofób) kolloidokhoz hasonlóan viselkednek. Ennek okát a nagymértékü hidratációban láttuk ${ }^{27}$. A víz diffúziós együtthatójának koncentrációfüggését pedig úgy értelmeztük, hogy vannak víz $\left(\mathrm{D}_{2} \mathrm{O}\right)$ molekulák, amelyek a dendrimerrel együtt diffundálnak, mások pedig szabadon mozognak. Mivel csak egy vízjelünk volt az NMR spektrumban, így a modellben azt is feltettük, hogy a cserefolyamat a dendrimerben lévő víz és a szabad víz között gyors az NMR kémiai eltolódás időskálán. Ebből az egyszerü modellből a dendrimerek víztartalma 3600 mol/mol-nak adódott, méghozzá úgy, hogy megokoltuk, hogy a dendrimer a vízre nézve tökéletesen átjárható. Az ilyen módon meghatározott hidratációs szám pontos definíciója: azoknak a vízmolekuláknak a száma, amelyek a makromolekulával egy dinamikai egységet képviselnek, de a diffúzió idöskáláján gyorsan cserélödnek a tömbfázissal. Ennek a számnak a realitását más módon, NMR krioprozimetriával is bizonyítottuk ${ }^{12}$. Szintén diffúziometria segítségével bizonyítottuk, hogy a foszfát puffer alkalmazása megváltoztatja a makromolekulás kolloidok viselkedését specifikus kölcsönhatások révén ${ }^{29}$.

\subsection{Kisterű NMR-relaxometria}

Az NMR relaxometria a relaxációs idő mérése alapján következtet a rendszerben molekulák részecskék méretére, szerkezetére és a közeggel való kölcsönhatásra. Mind a nagyfelbontású és kisfelbontású változata alkalmas a kolloid rendszerek vizsgálatára. Mi elsősorban a porózus rendszerek tanulmányozására alkalmazzuk. A nagyterü, vagy nagyfelbontású NMR-rel szemben előny az olcsósága és olcsóbb üzemeltetése. Természetesen hátránya a kisebb érzékenység, így elsősorban az oldószer sajátságait lehet vele követni. A kiértékelés komplikáltabb, de megjegyzendő, hogy az NMR hőskorában a matematikai alapokat már kidolgozták. Intézetünkben két Bruker MQ20 MiniSpec relaxométer üzemel, amelyek a rezonancia frekvenciája mindössze $20 \mathrm{MHz}$. Az egyik gradiens mérőfejjel és egységgel van felszerelve, így az oldószer relaxációsebessége mellett még a diffúzió mérésére is alkalmas.

A transzverzális relaxációs időt az un. CPMG (Carr, Purcell, Meiboom és Gill) impulzus szekvenciával mértük. Ekkor ún. spin ekhó jeleket generálunk, és mérjük azoknak az intenzitáscsökkenését az ekhóidő függvényében. A szokásos eljárás az, hogy multi-exponenciális függvényt illesztünk a csökkenő görbére, annyi elemböl állót, amennyi relaxációs idejü részecske van a rendszerben:

$$
I(t)=I_{\infty}+\left(\sum_{i=1}^{n} I_{i} e^{-t \frac{1}{T_{2}}}\right)
$$

A szilikagél esetében a víz lehet a határfelületen, ahhoz közel, attól távolabb, és kis pórusokba zárva. Ha a diffúzió elég gyors ahhoz, hogy a diffúzió ideje alatt a felületi, a felület közeli és a megtelt pórusokban lévő vízmolekulák átkerüljenek egyik pozícióból a másikba, akkor egy átlagos relaxációs időt mérünk, azaz a (3) egyenletben $n=1$. A leggyakrabban a két hely modellel írják le a rendszereket, amelyet a (4) egyenlet fejez $\mathrm{ki}^{18,30}$ :

$$
\frac{1}{T_{2}}=\frac{V_{S}}{V} \frac{1}{T_{2 s}}+\frac{V_{b}}{V} \frac{1}{T_{2 b}}
$$

A mért relaxációs idő a felületi $(s)$ és a tömbfázisbeli relaxációs idők $(b)$ térfogattört szerinti átlaga. Ha a pórusok között az oldószer csere lassú, akkor több átlagos relaxációs időpárt ( $s$ és $b$ ) mérhetünk, amelyek aránya a pórusmérettel kapcsolatba hozható ((5) egyenlet). A kiértékelés során nehézséget okoz, hogy a multiexponenciális illesztés nagyon gyengén kondicionált feladat ${ }^{31}$. Ennek alternatívája a kifejezetten erre a rendszerekre kifejlesztett Laplaceinverzió módszere, amely esetében nem kell elöre megadni az illesztendő exponenciális tagok számát $t^{32}$. Lényege, hogy először a mért intenzitást relaxációs időre, mint független változóra skálázzuk át:

$$
I(t)=I_{\infty}+\int_{0}^{\infty} T_{2} I\left(T_{2}\right) e^{-\frac{1}{T_{2}} t} d T_{2}
$$

Ezt követően megadjuk a relaxációs idő racionális minimumát és maximumát és több száz pontra osztjuk ezt az intervallumot, mindegyikhez egy-egy relaxációs időállandót rendelve. Ezekhez kiszámítjuk az exponenciális függvény értékét, majd pedig a legkisebb négyzetek módszerével megkeressük az $I\left(T_{2}\right)$ eloszlásfüggvényt, azaz a pre-exponenciális tényezőket. Tipikus számítási eredményt mutat az 5. ábra. Látható, hogy a mutatott aránynál kétféle relaxációsebességü vízmolekula található a szilikában.
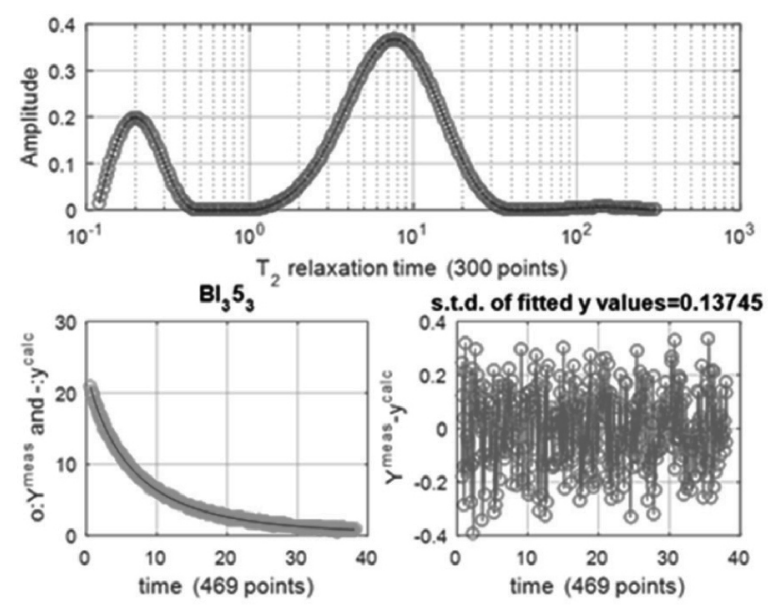

5. ábra Tipikus illesztési eredmény a multi-exponenciális relaxáció esetében, a MERA program kimeneti képe. Felül a kétféle relaxáció-eloszlást láthatjuk, alul a bal oldali képen az illeszkedés jóságát, a jobboldali képen pedig a százalékos eltéréseket pontonként. (32 $\mu 1$ víz/ 344 mg szilika) 
A 6. ábrán mutatjuk be a víz transzverzális relaxációs idejének változását a koncentráció függvényében egy Kieselgel 60 jelzésű szilikagél rendszerben a vízmennyiség függvényében. Az 6. ábrából a következő információkhoz juthatunk. A szilikagél pórusaiban a víz kezdetben adszorbeálódik a felületen. A formálisan nulla hozzáadott víztartalom esetén a levegőből adszorbeált víz relaxációs idejét mértük $(2,4 \mathrm{~ms})$.

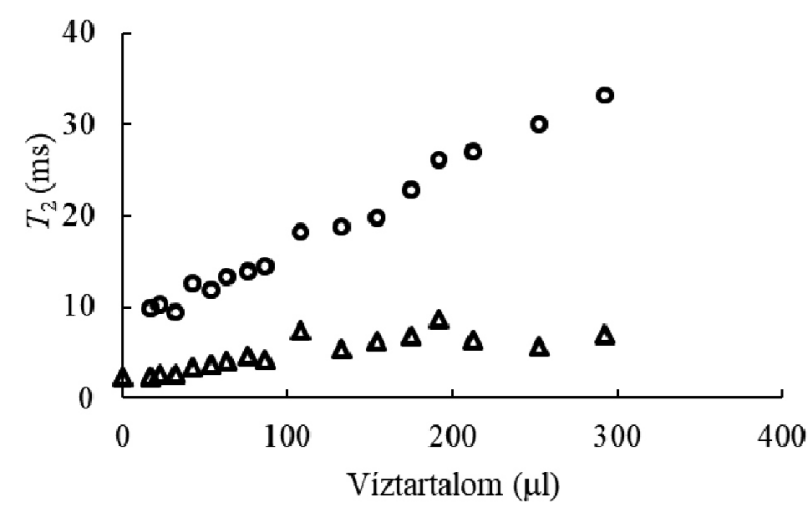

6. ábra A 344 mg Kieselgel 60-ba juttatott víz relaxációs idejének változása a hozzáadott vízmennyiség függvényében. A két pontsorozat kétféle víz jelenlétét jelzi.

A rövidebb relaxációs idő $25 \mu$ líz adagolásáig állandó, azaz adszorpció történik, majd enyhén növekszik, ami többrétegű adszorpcióra utal, ezután $100 \mu$ l-től nem változik. Ez a víz nincs kapcsolatban a pórusvízzel, és aránya gyakorlatilag lecsökken a kezdeti 80-90 \%-ról 2-5 \%-ra a növekvő vízmennyiséggel. A hosszabb relaxációs idejű víz először csak néhány \%-ban jelenik meg. A víz relaxációs idejének növekedése $100 \mu \mathrm{l}$-ig arra utal, hogy a pórusok sarkaiban ún. „tócsákat” képez. E tócsák növekednek, ami a relaxációs idő növekedésével jár, mert több lesz a vele kapcsolatban lévő tömbfázishoz hasonlatos víz. Az állandósult relaxációs idő 100 és $180 \mu \mathrm{l}$ között arra utal, hogy megtelnek a jól definiált pórusok, és csak azok száma gyarapszik. Ezt követően a Kieselgel 60 szemcséi közötti vizet mérjük. A pórusméret kiszámítása Allen és munkatársai szerint a következő módon történhet ${ }^{18,30}$.

$$
\left.\rho=\left\{1-\left[\left(\frac{T_{2 s}}{T_{2}}-1\right) /\left(\frac{T_{2 s}}{T_{2 h}}-1\right)\right]\right\}^{1 / 3}\right\}^{-1}
$$

Ahol a $\rho=r / l$ a dimenziómentes méret, ami azt adja meg, hogy az $r$ pórussugár hányszorosa az $l$ adszorbeált, azaz felületi vízréteg vastagságának. $T_{2}$ a mért transzverzális relaxációs idő, $T_{2 \mathrm{~s}}$ a felületi rétegben lévő víz, $T_{2 \mathrm{~b}}$ a pórus belsejében lévő víz relaxációs ideje. $\mathrm{Az}$ (5) egyenlet érvényességének feltétele az, hogy gömbi pórusok vannak, amelyeken belül kétfajta víz található: felületi és nem felületi, amely utóbbinak a relaxációs ideje azonos a tömbfázisbelivel. A kétfajta vízmolekula helycseréje gyors a relaxáció időskáláján, azaz kiátlagolódik a relaxációsebességük. A pórusméret meghatározhatósága két állandó értékének, $T_{2 \mathrm{~s}}$ és $l$ pontos ismeretétől függ. Az előbbi becsülhető a zérus víztartalomra extrapolált $T_{2}$-ből, míg az utóbbi pontos pórusméretü rendszer vizsgálatából egy bizonyos anyagfajtára meghatározható. A Kieselgel 60 gyártó szerinti legvalószínúbb pórussugara $3 \mathrm{~nm}$, míg a $T_{2 \mathrm{~s}} 2,5 \mathrm{~ms}-$ nak becsülhető (6. ábra). Ebből az $l$ értékét becsülhetjük élve azzal a feltevéssel, hogy 100 és $200 \mu$ l vízmennyiség között telnek meg a pórusok. A számítások azt mutatták, hogy a felületi vízréteg vastagsága 0,2 nm-nek adódik, ami megegyezik az irodalomban adott értékekkel ${ }^{18,30}$. Ez a két érték valószínüleg jól használható a szilikaféleségek pórusméretének relaxometriás meghatározásához. E méréssorozatnak éppenséggel az is volt a célja, hogy ehhez az adathoz hozzájussunk ${ }^{33}$. Megjegyezzük, hogy a két állandó kismértékü változása nagyobb eltéréseket okozhat a pórusméretben, ezért óvatosan kell eljárni a módszer alkalmazásakor. Jelentősége elsősorban a geokémiában, a kőzetek jellemzésénél és az olajiparban a viaszok olajtartalmának meghatározásánál $\operatorname{van}^{34-36}$. Léteznek olyan mérőfejek, amelyekkel a minta felületén lehet mérni, ezek elsősorban, amelyek a környezettudományokban alkalmazhatóak ${ }^{37}$.

\subsection{NMR krioporozimetria alkalmazása}

A pórusméret, illetve annak eloszlásának ismerete igen fontos. Meghatározására számos módszer ismeretes, azonban ezek többnyire más körülmények között történnek, mint ahogyan az alkalmazás. Az NMR kriopotozimetria nem invazív, általában nem változtatja meg a mérés a pórusméret-eloszlást. Példánkban a rezorcin-formaldehid szerves aerogél pórusméret-eloszlásának meghatározását mutatjuk be NMR krioporozimetriásan. A módszerrel nem csak a méreteloszlást, hanem a pórusalakot is meg tudtuk határozni. A rezorcin és a formaldehid polikondenzációjával egy olyan hidrogél jön létre, amelyből szuperkritikus extrakcióval aerogélt lehet készíteni. Ebből megfelelő karbonizálással szén aerogél nyerhető. Ennek széleskörü alkalmazási lehetőségét mutatták ki. Az NMR krioprozimetria vizes közegben képes megadni a pórusméret-eloszlást. A 7. ábra mutatja a vízzel feltöltött RF aerogél tipikus olvadás- és fagyásgörbéit.

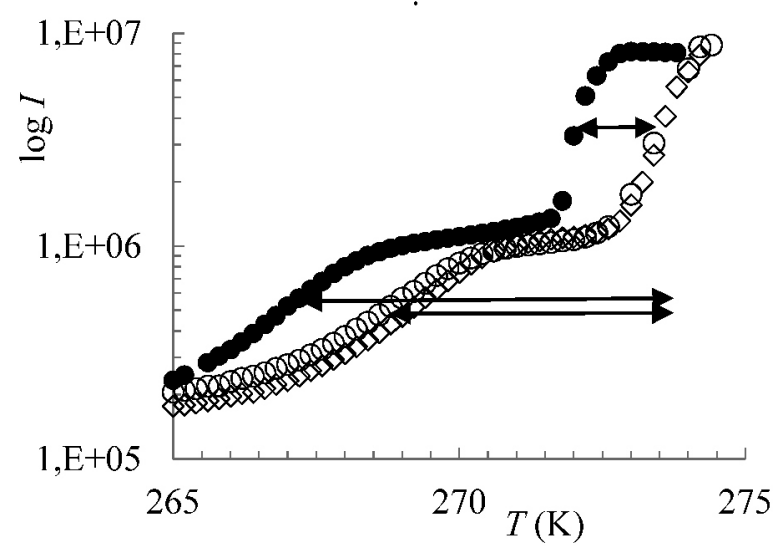

7. ábra A rezorcin-formaldehid aerogél NMR krioporozimetriás görbéje A $\bullet$ a fagyásgörbe, a $\diamond$ és o jelek két olvasztási periódus eredményét, és annak reprodukálhatóságát mutatják.

Látható az olvadásgörbe reprodukálhatósága is, valamint az olvadás és a fagyás folyamatának hiszterézise. Az első effektus esetén nem történt olvadáspont-csökkenés, de közelítőleg $1 \mathrm{~K}$ fagyáspontcsökkenés észlelhető (273,2-ről 
272,3-ra). Ez résalakú pórusra utal, és feltehetőleg a részecskék közötti vízréteg átlagos vastagságára jellemző, az értéke mintegy $30 \mathrm{~nm}$ ((2) egyenlet. A kisebb hőmérsékleten a két inflexiós pont távolságának aránya mintegy 1,5, ami gömb alakú pórusokra utal. A 8. ábra mutatja a fagyás- és az olvadásgörbéből számítható pórusméret-eloszlást, az olvadás- és fagyásgörbék grafikus differenciálásával előállítva. A legvalószínübb pórussugár $15 \mathrm{~nm}$-nek adódott és az eloszlás a 8. ábrán láthatóan közel Gauss-görbe jellegü.

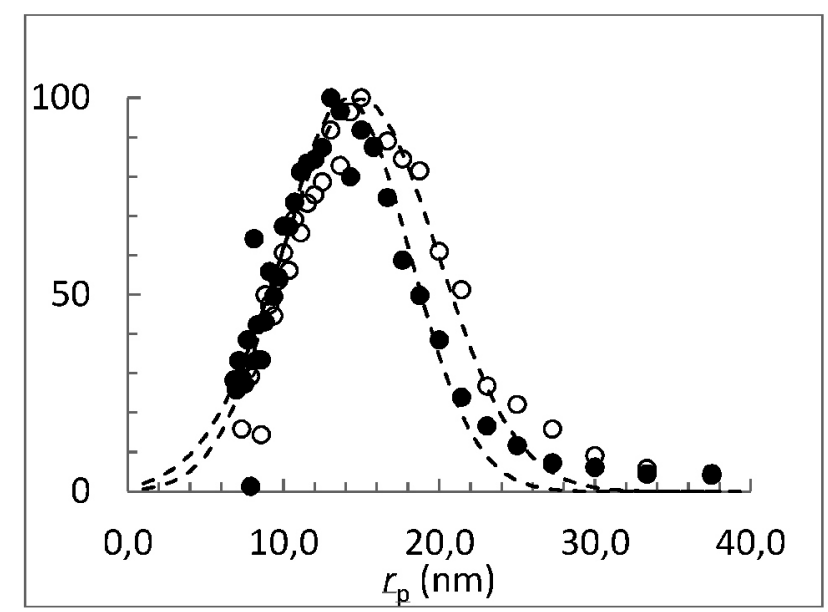

8. ábra A 7. ábrán látható, fagyás- és olvadásgörbék deriváltja látható, a vízszintes tengelyen a (2) egyenletből számítható méret van feltüntetve a hömérséklet helyett.

\section{Hivatkozások}

1. Helmholtz, R. v.; Annal. Phys. 1886, 263, 508 https://doi.org/10.1002/andp.18862630403

2. Fraissard, J.; Lapina, O.; Magnetic Resonance in Colloid and Interface Science, Eds. Kluwer Academic Publisher: Dordrecht, Boston, London, 2002 Vol. 76.

3. Palfy, G.; Kiss, B.; Nyitray, L.; Bodor, A. Chembiochem 2016, 17, 1829-1838.

https://doi.org/10.1002/cbic.201600280

4. Kardos, J.; Kiss, B.; Micsonai, A.; Rovo, P.; Menyhard, D. K.; Kovacs, J.; Varadi, G.; Toth, G. K.; Perczel, A. J. Phys. Chem. B 2015, 119, 2946-2955.

https://doi.org/10.1021/jp5124234

5. Hetenyi, A.; Hegedus, Z.; Fajka-Boja, R.; Monostori, E.; Kover, K. E.; Martinek, T. A.; J. Biomol. Nmr 2016, 66, 227-232. https://doi.org/10.1007/s10858-016-0076-3

6. Kovacs, T.; Batta, G.; Zakany, F.; Szollosi, J.; Nagy, P.; J. Lipid Res. 2017, 58, 1681-1691.

https://doi.org/10.1194/jlr.M077339

7. Nyden, M.; Holmberg, K.; Curr. Opin. Colloid Interface Sci. 2009, 14, 169-170.

https://doi.org/10.1016/j.cocis.2009.02.002

8. Schonhoff, M.; Curr. Opin. Colloid Interface Sci. 2013, 18, 201-213. https://doi.org/10.1016/j.cocis.2013.03.004

9. Mariette, F.; Curr. Opin. Colloid Interface Sci. 2009, 14, 203-211. https://doi.org/10.1016/j.cocis.2008.10.006

10. Vass, S.; Grimm, H.; Banyai, I.; Meier, G.; Gilanyi, T.; J. Phys. Chem. B 2005, 109, 11870-11874. https://doi.org/10.1021/jp051716p

11. Novak, L.; Banyai, I.; Fleischer-Radu, J. E.; Borbely, J.; Biomacromolecules 2007, 8, 1624-1632. https://doi.org/10.1021/bm0612182
Az így meghatározott pórusméret jól egyezik a nitrogén adszorpciós mérésekből becsült értékkel ${ }^{38}$. Az NMR krioporozimetria értékes alternatívája lehet az egyéb módszereknek, mert abban a közegben határozható meg a pórusméret-eloszlás, ahol alkalmazzuk a szilárd fázist, illetve tanulmányozhatjuk a folyadékok hatását a száraz állapotban mért pórusméretre. A módszert sikeresen alkalmaztuk lágy anyagok esetében is, meg tudtuk határozni a dendrimerek üregeinek lehetséges méretét is ${ }^{12}$.

\section{Köszönetnyilvánítás}

A kutatás a GINOP-2.3.2.-15-2016-00008 számú projekt keretében, az Európai Unió támogatásával, az Európai Regionális Fejlesztési Alap társfinanszírozásával, valamint az Emberi Erőforrások Minisztériuma ÚNKP-17-2 Új Nemzeti Kiválóság Programjának támogatásával valósult meg. A szerzők egyike (B.I) köszönettel tartozik prof. Dr. Ioan Ardeleannak (Kolozsvári Müszaki Egyetem, Románia) a relaxometriában nyújtott önzetlen segítségéért.

12. Keri, M.; Peng, C.; Shi, X. Y.; Banyai, I.; J. Phys. Chem. B 2015, 119, 3312-3319. https://doi.org/10.1021/acs.jpcb.5b00272

13. Gunko, V. M. Turov, V. V. NUCLEAR MAGNETIC RESONANCE STUDIES OF INTERFACIAL PHENOMENA CRC Press: Boca Raton, 2010.

14. He, X. D.; Alves, C. S.; Oliveira, N.; Rodrigues, J.; Zhu, J. Y.; Banyai, I.; Tomas, H.; Shi, X. Y.; Colloids Surf. B-Biointerfaces 2015, 125, 82-89. https://doi.org/10.1016/j.colsurfb.2014.11.004

15. Vögtle, F.; Richardt, G.; Werner, N. Dendrimer Chemistry: Concepts, Syntheses, Properties, Applications Wiley-VCH Verlag GmbH: Weinheim, 2009. https://doi.org/10.1002/9783527626953

16. Johnson, C. S. Prog. Nucl. Magn. Reson. Spectrosc. 1999, 34, 203-256. https://doi.org/10.1016/S0079-6565(99)00003-5

17. Cohen, Y.; Avram, L.; Frish, L.; Angew. Chem. Int. Ed. 2005, 44, 520-554. https://doi.org/10.1002/anie.200300637

18. Allen, S. G.; Stephenson, P. C. L.; Strange, J. H. J. Chem. Phys. 1998, 108, 8195-8198. https://doi.org/10.1063/1.476175

19. Bede, A.; Scurtu, A.; Ardelean, I. Cem. Conc. Res. 2016, 89, 56-62. https://doi.org/10.1016/j.cemconres.2016.07.012

20. Farrher, G.; Ardelean, I.; Kimmich, R.; J. Magn. Reson. 2006, 182, 215-220. https://doi.org/10.1016/j.jmr.2006.06.032

21. Farrher, G.; Ardelean, I.; Kimmich, R. Appl. Magn. Reson. 2008, 34, 85-99. https://doi.org/10.1007/s00723-008-0096-6

22. Petrov, O. V.; Furo, I. Prog. Nucl. Magn. Reson. Spectrosc. 2009, 54, 97-122. https://doi.org/10.1016/j.pnmrs.2008.06.001 
23. Strange, J. H.; Rahman, M.; Smith, E. G. Phys. Rev. Lett. 1993, 71, 3589-3591. https://doi.org/10.1103/PhysRevLett.71.3589

24. Zhang, M. G.; Guo, R.; Keri, M.; Banyai, I.; Zheng, Y.; Cao, M.; Cao, X. Y.; Shi, X. Y. J. Phys. Chem. B 2014, 118, 1696-1706. https://doi.org/10.1021/jp411669k

25. Keri, M.; Palcsu, L.; Turi, M.; Heim, E.; Czebely, A.; Novak, L.; Banyai, I. Cellulose 2015, 22, 2211-2220. https://doi.org/10.1007/s10570-015-0642-y

26. Banyai, I.; Lakatos, I.; Meier, G.; Nagy, Z.; Vass, S. Bull. Chem. Soc. Jpn. 2017, 90, 854-862. https://doi.org/10.1246/bcsj.20170050

27. Banyai, I.; Keri, M.; Nagy, Z.; Berka, M.; Balogh, L. P. Soft Matter 2013, 9, 1645-1655. https://doi.org/10.1039/C2SM26726H

28. Dhont, J. K. G. An Introduction to the Dyanmics of Colloids Elsevier: Amsterdam, 1998.

29. Keri, M.; Nagy, Z.; Novak, L.; Szarvas, E.; Balogh, L. P. Banyai, I.; Phys. Chem. Chem. Phys. 2017, 19, 11540-11548.

30. Allen, S. G.; Stephenson, P. C. L.; Strange, J. H. J. Chem. Phys. 1997, 106, 7802-7809. https://doi.org/10.1063/1.473780
31. Tikhonov, A. N. Arsenin, V. Y. Solutions of ill posed problems W. H. Winston and Sons, (distributed by Wiley,): New York, 1977.

32. Does, M. D. http://www.vuiis.vanderbilt.edu/ doesmd/ MERA/MERA_Toolbox.html

33. Kalmar, J.; Keri, M.; Erdei, Z.; Banyai, I.; Lazar, I.; Lente, G.; Fabian, I. Rsc Advances 2015, 5, 107237-107246. https://doi.org/10.1039/C5RA21353C

34. Ayalur-Karunakaran, S.; Blumich, B.; Stapf, S. Eur. Phys. J. E 2008, 26, 43-53. https://doi.org/10.1140/epje/i2007-10341-x

35. Presciutti, F.; Perlo, J.; Casanova, F.; Gloggler, S.; Miliani, C.; Blumich, B.; Brunetti, B.; G. Sgamellotti, A. Appl. Phys. Lett. 2008, 93. DOI: $10.1063 / 1.2963026$ https://doi.org/10.1063/1.2963026

36. Song, Y. Q. J. Magn. Reson. 2013, 229, 12-24. https://doi.org/10.1016/j.jmr.2012.11.010

37. Blumich, B.; Perlo, J.; Casanova, F. Prog. Nucl. Magn. Reson. Spectrosc. 2008, 52, 197-269. https://doi.org/10.1016/j.pnmrs.2007.10.002

38. Nagy, B.; Czakkel, O.; Laszlo, K. Micropor. Mesopor. Mater. 2014, 185, 66-71. https://doi.org/10.1016/j.micromeso.2013.11.004

\section{Application of Nuclear Magnetic Resonance Spectroscopy (NMR) for Physico-Chemical Characterization of Colloid Systems}

Physical chemistry, in general, gained a lot from studying colloids. These studies contributed to clarifying the exact definitions of surfaces, particles, phases etc. Nowadays the physical chemistry of colloids becomes extremely important because the high rate of progress in molecular biology requires this knowledge. Furthermore, the "nano age" is our present. We witness an explosion in nanoscience and nanotechnology. The key feature of this branch of physical chemistry is self-assembly. In practice we cannot produce nanoparticles but let them form as directed by the laws of stability, formation, structure, and particle dynamics. When the nanoparticles are "ready" the characterization is a vital point for their application in the industry or pharmacy.

Nuclear magnetic resonance spectroscopy since the 1950s has become one of the most important tools for characterizing the equilibrium, dynamics and structure of materials. However, this method became an indispensable technique for characterizing nanometer-sized particles only in the last two decades, mainly for structural analysis of bio-macromolecules. In this paper, we show that beyond the classical 1D chemical shift and 2D correlation NMR spectroscopy other types of NMR methods can very often be used to characterize not only organic macromolecules but dispersion colloids or micellar systems as well. Moreover, for the solid porous materials, liquid NMR spectroscopy is a very powerful method to determine the pore size distribution. This paper does not deal with solid state NMR because it is very different from liquid state NMR either in theory or in practice. We rather deal in details with three methods: relaxometry, diffusiometry and NMRcryoporometry besides the usual NMR applications. In order to make these tools attractive, we shortly summarize the basic theory concerning them and show a few examples from our own research made during the last decade.
First, we show that ${ }^{13} \mathrm{C}$-NMR can easily be used to determine the degree of functionalization of a macromolecular chelating agent (Figure 2). In this case the high chemical shift range of ${ }^{13} \mathrm{C}$-NMR helped us to determine the degree of decoration of the well-known polyethylene-imine platform with chelating groups. This macromolecule is a very promising nano-sized chelating agent for transition metal ions.

The interaction of poly-amido-amine dendrimers of generation 5 (G5_PAMAM. $\mathrm{NH}_{2}$ ) with a small organic molecule, the drug doxorubicin, is discussed with $1 \mathrm{H}-1 \mathrm{H} 2 \mathrm{D}$ NOESY spectrum (Figure 3). NOESY is very useful to detect secondary interactions because cross-relaxation, the reason of the appearance of cross peaks, is determined by the spatial vicinity of groups even if there is a primary chemical bond between them. We could not find cross peaks between the drug and the dendrimer platform, however the phase of cross peaks between protons within the drug were in identical phase compared to the diagonal peaks. It is a clear indication from the long rotational correlation time that is the drug molecule is inside of a large particle.

NMR diffusiometry is used to determine the hydrodynamic size of particles containing NMR active nuclei. However it is usually forgotten that one should measure the diffusion coefficient as a function of the concentration and extrapolate the $D$ value to zero, otherwise the obstruction effect causes false results in size. Furthermore the concentration dependence gives information on the association properties. The highly hydrated dendrimers behave like hard spheres, ideal lyophobic colloids, nonetheless that G5_PAMAM. $\mathrm{NH}_{2}$ was expected to be highly associated. The concentration dependence of their apparent diffusion coefficient proved that there is no specific interaction between their $\mathrm{NH}_{2}$ end groups. (Figure 4) The most probable reason is that water hydrates the end groups and prevents the interaction between 
them. By measuring the diffusion rate of water in the presence of G5_PAMAM dendrimers we found that the hydration number can also be calculated and is as high as $3600 \mathrm{~mol} / \mathrm{mol} \mathrm{macromolecule}$.

Low field NMR relaxometry is widely used in geochemistry and in the oil industry. It does not provide high resolution NMR spectra but it can measure relaxation rates and diffusion coefficients very effectively. The main advantage of these relaxometers is the low price and low maintenance requirement. The basic method used is the titration of porous materials with a solvent and measurement of the change in relaxation time. According to our experiences this method can provide information about the wettability of surfaces of porous materials and about the mechanism of wetting. In certain cases it is even applicable for pore size determination. However it suffers from the lack of the knowledge about the surface relaxivity and that of the thickness of the surface layer. Kieselgel-60 silicagel with known pore size provided information about the thickness of the adsorbed layer of water molecules on silica species in general. Therefore measurement of the relaxation time distribution of Kieselgel 60 makes possible to determine the mechanism of wetting and the size of pores of other newly prepared silica based materials. (Figure 6) We are on the way to extend this method for other types of aerogels with the combination of NMR cryoporometry. Low field NMR diffusiometry can also be used for pore size determination of macropores by using the concept of hindered diffusion, however the application requires high computational care because the full process cannot be described by analytical equations, only some approximate formulas are available.

NMR cryoporometry is based on the famous GibbsThomson equation introduced to describe the phase transfer temperature for liquids confined in small volumes of solids, typically porous materials. NMR brought a breakthrough in this classical method because it is able to detect quantitatively the molten solvent as a function of temperature. Therefore we are able to construct melting-freezing curves (Figure 7). From these experiments the pore size distribution can be calculated for solids, like aerogels in solution (Figure 8). This method looks very promising because it is non-invasive and contrary to mercury porometry it can be used for soft material, like gels. We successfully used this method for dendrimers and aerogels. This method has a possibility to determine the pore shape as well. Disadvantage of the NMR cryoporometry is that the constants in the Gibbs-Thomson equation should be determined experimentally using known pore size material. It depends on the solvent used but also on the interface tensions which are determined by the solid as well. The limits of pore size which can be determined vary from $2-5 \mathrm{~nm}$ to $100 \mathrm{~nm}$.

This paper summarizes NMR-related activity of the colloid group of the Department of Physical Chemistry, the former Department of Colloid and Environmental Chemistry, of the University of Debrecen. We have published about 30 papers in the last decade on this subject in collaboration with Hungarian and international partners. The goal of this paper is to encourage colloid chemists to use NMR spectroscopy and to enlighten for them the gain which can be obtained from NMR. Normally the NMR labs are accessible through specially trained operators who are, as a matter of fact, professional in high resolution multidimensional methods for organic chemistry. This communication hopefully helps to bring closer colloid chemistry to the operators and facilitate the communication between colloid chemists and NMR experts. 